\title{
Peran Orang Tua dalam Menumbuhkan Pribadi Anak yang Androgynius Melalui Kegiatan Bermain
}

\author{
Muthmainnah \\ diwan nafil@yahoo.co.id \\ PGPAUD FIP Universitas Negeri Yogyakarta
}

\begin{abstract}
Abstrak
Anak memiliki potensi kepribadian sesuai dengan gaya pengasuhan dan warna lingkungan. Sebagai orang tua sudah menjadi suatu keniscayaan untuk bisa memberikan yang terbaik bagi anak-anaknya. Tidak sekedar mencarikan sekolah terbaik untuk anak, tetapi memberikan kasih sayang dengan membantu anak mencapai tugas perkembangannya. Salah satu tugas perkembangan yang perlu dicapai adalah mengenal diri dan lingkungan. Anak-anak dapat mengenal diri dan lingkungannya melalui kegiatan bermain yang merupakan dunia mereka. Melalui bermain, salah satu aspek yang dapat dikembangkan adalah aspek sosial-emosional, termasuk di dalamnya adalah kepribadian. Kepribadian anak laki-laki identik dengan sisi maskulinitas, sedangkan anak perempuan identik dengan sisi feminitas. Anak laki-laki yang hanya dibiasakan untuk mengembangkan sisi maskulinitasnya dan anak perempuan yang hanya dikondisikan untuk menumbuhkan sisi feminitasnya dikhawatirkan akan tumbuh menjadi pribadi yang timpang dan terlalu kaku. Upaya untuk mencegah tumbuhnya kepribadian yang timpang dan terlalu kaku dapat dilakukan dengan mengkondisikan anak agar memiliki pribadi yang androgynius, yaitu pribadi yang memiliki kecenderungan sifat seimbang.
\end{abstract}

Kata kunci: Anak, Kepribadian, Maskulinitas, Feminitas

\begin{abstract}
Children have potential of personality that fits with the style of parenting and the color of environment. As people become parents, it is a necessity to be able to give their best to their children. It is not only finding the best school for the children, but also giving their love to help their children reach their development tasks. One of the development tasks that need to be achieved is knowing oneself and the environment. Children can recognize themselves and their environment through playing activities that constitute their world. One aspect that can be developed through playing is social emotional including the personality. Boy's personality is synonymous with masculinity side while girls are identical with femininity side. Boys who are only accustomed to develop their masculinity and girls who are only conditioned to cultivate their femininity side are worried to grow into lame and too rigid persons. Some efforts to prevent the children from growing into lame and too stiff personality are done by conditioning the children to have androgynous personality, i.e., a person who has tendency to have a balance nature.
\end{abstract}

Keywords: parents, children, personal androgynous, play 


\section{Pendahuluan}

Setiap orang tua mendambakan anaknya menjadi anak yang cerdas dan bermanfaat. Cerdas dari sisi kemampuan kognitif atau intelektual, cerdas spiritual, dan cerdas eksistensial. Terdapat beberapa faktor yang mempengaruhi kecerdasan anak yaitu faktor genetik (bawaan) dan faktor lingkungan. Untuk mewujudkan harapan memiliki anak cerdas, upaya yang dilakukan tidak sekedar mem-berikan asupan gizi yang seimbang, mengasuh dan mendidik dengan baik, mengupayakan lingkungan yang "se-hat" dan memberikan fasilitas, tetapi juga mengupayakan lingkungan psi-kologis yang kondusif. Lingkungan psikologis yang kondusif dapat memberikan rasa aman dan nyaman, sehingga anak akan tumbuh menjadi anak yang memiliki rasa percaya diri (self-confidence) dan memiliki keyaki-nan pada kemampuannya (self-efficacy). Dalam hal ini, orang tua memiliki peran penting untuk membantu anak mengembangkan potensi dan mencapai tugas perkembangannya.

Salah satu aspek psikologis yang perlu dikembangkan pada anak adalah kepribadian. Sisi kepribadian kadang kala menjadi aspek yang terabaikan dan terkesan kurang penting daripada aspek kognitif. Saat anak mendapatkan nilai tidak baik, maka orang tua terlihat kecewa atau bahkan sangat kecewa yang seringkali ditunjukkan dengan kemarahan. Namun saat orang tua melihat anaknya menyayangi binatang peliharaannya, rukun ketika bermain dengan teman-temannya dan membantu temannya yang kesulitan, hal ini dianggap hal sepele yang sepertinya tidak perlu diberikan komentar dan penguatan positif. Tentunya pemikiran seperti ini perlu direnungkan kembali dan dikoreksi. Orang tua yang terlalu menitikberatkan anak pada kemampuan kognitifnya saja dan mengabaikan kemampuan lainnya perlu mempertim- bangkannya lagi. Pengasuhan tidak hanya berfungsi sebagai pengembangan kompetensi, tapi juga berfungsi sebagai pengembangan karakter yang meliputi tanggung jawab sosial yang positif, komitmen moral, dan disiplin diri, pengaturan pikiran dan kehendak. Membantu anak menjadi pribadi yang sehat, seimbang dan mampu menyesuaikan diri dengan lingkungan dan zamannya merupakan harapan kita bersama. Apalagi saat ini anak adalah milik zaman dan zaman semakin penuh dengan tantangan. Orang tua perlu membekali anak dengan sisi spiritual dan sosialemosional yang matang, sehingga anak-anak memiliki kepribadian yang baik. Kepribadian baik identik dengan kepemilikan budi pekerti. Salah satu kepribadian yang perlu dikembangkan adalah pribadi androgynius, yaitu pribadi yang seimbang.

\section{Kepribadian}

Setiap individu memiliki kepribadian (personality). Makna kepribadian kadangkala jumbuh dengan makna karakter. Pada dasarnya karakter merupakan bagian dari kepribadian. Individu setiap saat selalu berhubungan dengan lingkungan sosial, maka yang dapat diketahui orang terlebih dahulu adalah karakter. Secara etymology, personality atau kepribadian berasal dari kata personal yang bermakna: 1) topeng yang dimainkan ole pemain drama untuk menjalankan suatu rol tertentu; dan 2) menunjukkan "the true self" atau "the inner man" (Sri Rumini dkk, 1998).

Ki Hajar Dewantara berpendapat bahwa anak belum memiliki budi pekerti tertentu, belum memiliki bentuk jiwa yang tetap dan masih bersifat global. Hal senada diungkapkan oleh John Locke yang menyatakan bahwa anak ibarat kertas putih. Lingkunganlah yang nantinya akan mewarnai sisi individu, baik sisi kognitif maupun kepribadiannya. Anak 
yang diasuh oleh orang tua yang memiliki pola asuh baik tentunya akan menjadi pribadi yang baik. Pola asuh yang baik adalah pola asuh yang bisa menempatkan pada situasi dan kondisi anak yang dapat mendukung perkembangannya. Keluarga memiliki peran strategis dan krusial untuk dapat mengantarkan anaknya menjadi pribadi yang baik dan bermanfaat bagi lingkungannya.

\section{Pribadi Androgynius dan Urgensinya}

Anak sangat menyukai kegiatan bermain karena dianggap menyenangkan. Melalui kegiatan bermain, anak sekaligus dapat mengembangkan aspek perkembangannya, baik aspek nilai dan moral, kognitif, fisik-motorik, bahasa, dan sosial-emosional. Bermain menjadikan anak menjadi sehat karena bergerak bebas, terlatih pola pikirnya untuk membuat strategi bermain dan terasah hatinya untuk bersikap sportif, menaati aturan bersama dan mengenal berbagai karakter temannya. Interaksi dengan teman-teman saat bermain merupakan salah satu kebutuhan anak yang dapat membantu tumbuh kembangnya di masa depan.

Jenis permainan yang dilakukan anak umumnya dibedakan berdasarkan jenis kelamin. Perbedaan jenis hormon, bentuk tubuh dan kekuatan menjadi faktornya. Anak laki-laki yang cenderung kuat lebih memilih permainan yang aktif dan kasar. Sedangkan anak perempuan memilih permainan yang lembut, memerlukan pembicaraan dan tidak banyak memerlukan kekuatan fisik. Kecenderungan alami ini akan membantu menumbuhkan kepribadian feminin bagi anak perempuan dan menumbuhkan watak maskulin bagi anak laki-laki (Irawati Istadi, 2007). Yang me-njadi pertanyaannya, apakah membedakan permainan berdasarkan jenis kelamin adalah hal yang benar dan sejauhmana hal ini mempengaruhi kepribadian anak? Tampaknya hal ini perlu menjadi pemikiran.

Dalam kesehariannya dapat kita amati bahwa orang tua akan membiasakan dan mengkondisikan anak sesuai dengan jenis kelaminnya. Misalnya anak laki-laki akan dibiasakan untuk menggunakan celana, bermain yang maskulin seperti berlarian, tembak-tembakan, bermain bola dan kelereng. Sedangkan jika anak laki-laki bermain dengan boneka dan masakmasakan, maka hal ini kadangkala dianggap aneh. Begitu pula sebaliknya, anak perempuan cenderung dilarang untuk memanjat dan bermain bola. Anak perempuan lebih dikondisikan dengan permainan yang lebih menumbuhkan sisi feminitasnya seperti permainan masak-masakkan. Padahal seorang anak laki-laki perlu memahami perasaan anak perempuan dan sebaliknya, anak perempuan diharapkan untuk memahami pula perasaan lawan jenisnya. Agar bisa memahami perasaan lawan jenisnya maka orang tua perlu mengenalkan anak pada kebiasaan dan kecenderungan lawan jenis semasa kecil.

Anak laki-laki yang hanya dibiasakan untuk mengembangkan sisi maskulin semata dan anak perempuan yang hanya dikondisikan untuk menumbuhkan sisi feminitasnya semata dikhawatirkan akan tumbuh menjadi pribadi yang timpang dan terlalu kaku. Upaya untuk mencegah tumbuhnya kepribadian yang timpang dan terlalu kaku dapat dilakukan dengan mengkondisikan anak agar memiliki pribadi yang androgynius, yaitu pribadi yang memiliki kecenderungan sifat seimbang. Seimbang tidak dimaknai sebagai separuhseparuh atau fifty-fifty, tapi seimbang dalam kadar sesuai dengan keadaan dan kebutuhan (Irawati Istadi). Anak laki-laki tumbuh sebagaimana karakter dan sifat kelaki-lakiannya, namun tetap memiliki sifat feminin dalam kadar secukupnya seperti sabar, 
telaten dan lembut. Begitu pula anak perempuan, selain memiliki kepribadian feminin namun juga perlu memiliki sifat maskulin seperti tegas, pemberani dan menyukai tantangan.

Pada umumnya anak yang memiliki pribadi androgynius akan lebih mudah menyesuaikan diri dan diterima dalam pergaulan di masyarakat. Bagi anak laki-laki, ia akan tumbuh menjadi pribadi yang bersikap lembut, penyayang dan sabar dalam menghadapi dan membantu perempuan, termasuk ibu, saudara perempuannya, teman perempuannya bahkan istrinya kelak. Anak laki-laki akan menjadi sosok yang menyayangi dan melindungi keluarganya. Ia pun tidak segan untuk membantu pekerjaan perempuan seperti memasak, merawat bayi atau anak, memasak atau membersihkan rumah. Sebaliknya perempuan yang memiliki pribadi androgynius akan tampil sebagai sosok perempuan yang lembut tapi tegas, kuat (tegar), percaya diri dan mandiri. Perempuan dilatih untuk mandiri dan tidak bergantung pada laki-laki dan tampil percaya diri dengan wawasan pemikirannya yang luas.

\section{Relevansi Bermain dan Kepribadian}

Dunia anak adalah dunia bermain. Melalui kegiatan bermain, anak belajar banyak hal. Bermain merupakan bagian yang amat penting dalam tumbuh kembang anak untuk menjadi manusia seutuhnya (Dwi Sunar Prasetyono, 2007). Anak-anak menggunakan sebagian besar waktunya untuk bermain, baik dengan dirinya sendiri maupun dengan temannya. Bermain memiliki esensi dalam mendukung tumbuh kembang anak. Tidak hanya sekedar mengembangkan aspek fisik motorik saja, namun juga mengembangkan aspek nilai-nilai dan moral, kognitif, bahasa, dan sosial-emosional.
Dilihat dari segi aspek sosialemosional, melalui kegiatan bermain anak dapat dilatih untuk memahami adanya aturan main dan mau menaatinya. Selain itu, anak dapat dilatih untuk bersikap kooperatif dan menunjukkan antusiasme dalam melakukan permainan kompetitif secara positif. Anak dibiasakan untuk mengembangkan sikap gigih untuk mencapai kemenangan dan memiliki sportif. Tujuan tersebut sesuai dengan isi dari standar PAUD yang tertuang dalam Permendiknas No 58 tahun 2009. Hal ini didukung dengan pendapat Slamet Suyanto (2003) bahwa pada saat anak berinteraksi dengan anak yang lain, maka secara tidak langsung mengajarkan anak bagaimana merespon, memberi dan menerima, menolak atau setuju terhadap ide dan perilaku anak lain.

Di sisi lain melalui kegiatan bermain, anak laki-laki dapat mengamati dan memahami karakteristik anak perempuan. Sebaliknya, anak perempuan pun bisa mencermati dan mengenal karakteristik anak laki-laki. Apabila anak laki-laki hanya bermain perang-perangan, mobil-mobilan dan ditertawakan atau dipermalukan ketika memegang boneka, maka hal ini perlu dipikirkan kembali. Bisa jadi dengan bermain boneka dan masak-masakan, anak laki-laki akan terasah feminitasnya, sehingga akan tumbuh rasa kasih sayang dan mampu bersikap lembut. Begitu pula anak perempuan, apabila anak perempuan diperbolehkan memanjat dan berlarian, maka memungkinkan anak perempuan akan tumbuh menjadi pribadi pe-mberani dan lincah. Tentunya sisi yang berbeda tersebut perlu diperhatikan porsinya, agar kekhawatiran orang tua kalau anak laki-lakinya diejek dengan istilah bencong dan anak pe-rempuannya tumbuh menjadi anak ya-ng terlalu tomboy tidak akan terjadi. 


\section{Pola Asuh Orang Tua}

Baumrind membagi pola asuh menjadi tiga macam, yaitu otoritatif, otoritarian dan permisif. Pola asuh otoritatif memiliki karakteristik antara lain: mengarahkan anak secara rasional, berorientasi pada tindakan atau perbuatan, mendorong komunikasi lisan, memberi penjelasan atas keinginan dan tntutan yang diberikan tapi juga menggunakan kekuasaan jika diperlukan, mengharapkan anak untuk menyesuaikan dengan harapan orang tua tapi juga mendorong untuk mandiri, menetapkan standar perilaku secara fleksibel. Sedangkan ka-rakteristik pola asuh otoritarian antara lain: membentuk, mengontrol, mengevaluasi sikap dan perilaku anak dengan menggunakan standar yang absolut dan kaku, menekankan pada kepatuhan, penghormatan, kekuasaan dan tradisi serta menjaga keteraturan dan kurang menjalin komunikasi lisan. Pola asuh permisif memiliki karakteristik antara lain: memiliki sikap positif pada anak, sedikit menggunakan hukuman, membiarkan anak mengatur perilakunya, tidak banyak menuntut anak, dan menghindari pengontrolan dan menggunakan rasional dalam mencapai tujuan.

Orang tua yang bersikap otoriter dan yang memberikan kebebasan penuh menjadi pendorong bagi anak untuk berperilaku agresif. Sedangkan orang tua yang bersikap demokratis tidak memberikan andil terhadap perilaku anak untk agresif dan menjadi pendorong terhadap perkembangan anak ke arah yang positif. Dijelaskan pula bahwa dalam pola asuh dan sikap orang tua yang demokratis menjadikan adanya komunikasi yang dialogis antara anak dan orang tua dan adanya kehangatan yang membuat anak merasa diterima oleh orang tua, sehingga ada pertautan rasa (M Sochib, 2000).

Dalam mendidik anak, orang tua memiliki gaya asuh. Gaya asuh menurut J ane Nelsen dibagi menjadi 3 gaya (http://n4il4.multiply.com/journal). Gaya tersebut antara lain:

\begin{tabular}{|c|c|}
\hline $\begin{array}{l}\text { Model } \\
\text { Pendidikan }\end{array}$ & Ciri-ciri \\
\hline \multirow[t]{3}{*}{$\begin{array}{l}\text { Gaya Keras } \\
\text { (Terlalu dikontrol) }\end{array}$} & $\begin{array}{lr}\text { Memerintah } & \text { secara } \\
\text { kaku tanpa } & \text { memberi } \\
\text { kebebasan. } & \end{array}$ \\
\hline & $\begin{array}{l}\text { Tak ada pilihan lain, } \\
\text { harus dituruti. }\end{array}$ \\
\hline & $\begin{array}{l}\text { "Kamu } \\
\text { melakukannya, karena } \\
\text { itu perintahku”. }\end{array}$ \\
\hline \multirow{3}{*}{$\begin{array}{l}\text { Gaya Lunak } \\
\text { (Tanpa batas) }\end{array}$} & Bebas tanpa batas. \\
\hline & Bebas memilih. \\
\hline & $\begin{array}{lr}\text { "Kamu } & \text { boleh } \\
\text { melakukan } & \text { apapun } \\
\text { yang kamu mau". }\end{array}$ \\
\hline \multirow[t]{3}{*}{$\begin{array}{l}\text { Gaya } \quad \text { Disiplin } \\
\text { Yang Positif }\end{array}$} & $\begin{array}{lll}\begin{array}{l}\text { Bebas } \\
\text { batasnya. }\end{array} & \text { tapi } & \text { ada } \\
\end{array}$ \\
\hline & Pilihan terbatas. \\
\hline & $\begin{array}{l}\text { "Kamu boleh memilih } \\
\text { apapun asal dalam } \\
\text { batas yang ditentukan". }\end{array}$ \\
\hline
\end{tabular}

Orang tua yang memilih gaya mendidik yang satu akan berbeda pandangan dan sikap dari orang tua yang memilih gaya mendidik lainnya. Berikut ini penjelasan dari ketiga gaya atau pola asuh menurut J ane Nelsen.

1. Gaya keras:

"Ini peraturan yang harus kamu taati dan jika tidak kamu taati, kamu akan dihukum". J adi anak tidak ikut mempengaruhi keputusan. Ibaratnya anak adalah terdakwa dan orangtua adalah hakim.

2. Gaya Lunak

"Tidak ada peraturan ketat. Kami yakin kita semua akan hidup saling menyayangi dan bahagia. Kelak anak akan bisa memilih peraturanmu sendiri kelak. Jika anak melakukan sesuatu yang bagus, akan kami beri hadiah".

3. Gaya Disiplin Yang Positif

"Kita bisa sama-sama menentukan peraturan mana yang sama-sama menguntungkan (win-win solution) dan apa solusi yang diperlukan jika ada masalah. Jika mama atau papa harus menentukan keputusan tanpa masukan dari kalian (anak-anak), 
kita akan tegas tetapi sayang, tetap menghormati kalian tanpa menjatuhkan harga diri kalian.

(http:// n4il4.multiply.com/journal)

Pola asuh dapat mempengaruhi kepribadian anak. Kepribadian anak terbentuk melalui pembiasaan dalam kehidupan sehari-hari, baik di rumah maupun di lingkungan luar rumah. Oleh karena itu, orang tua perlu mempertimbangkan dan mengkompromikan pola asuh atau gaya asuh manakah yang akan diterapkan pada anak, sehingga tujuan untuk membantu perkembangan anak akan tercapai. Sebagai orang tua tentunya ayah dan ibu harus memiliki aturan yang sama dalam mengasuh. Dari beberapa gambaran beberapa tipe atau pola asuh, memang tidak semua tipe dapat diterapkan untuk semua anak. Secara umum pola demokratis dianggap menghasilkan anak-anak yang patuh dan taat, sedangkan pola permisif dikritik sebagai bukan bentuk disiplin (Suryadi, 2007).

\section{Pendidikan Anak dalam Keluarga}

Setiap orang tua mendambakan anaknya memiliki budi pekerti luhur dan berhasil. Sebagai upaya untuk mencapai tujuan tersebut, maka pendidikan keluarga memiliki urgensi yang pertama dan utama. Hal ini dipaparkan oleh Ki Hajar Dewantara (M Sochib, 2000) bahwa keluarga merupakan "pusat pendidikan" yang pertama dan terpenting karena sejak timbulnya adab kemanusiaan sampai saat ini, keluarga selalu mempengaruhi pertumbuhan budi pekerti tiap-tiap manusia. Di samping itu, orang tua dapat menanamkan benih kebatinan yang sesuai dengan kebatinannya sendiri ke dalam jiwa anak-anaknya.

Upaya untuk memantapkan kepribadian anak tampaknya bukan suatu hal yang mudah. Orang tua perlu menetapkan suatu pola dan perlu adanya kekompakan antara ayah dan ibu. Selain itu, kepribadian anak di- pengaruhi juga oleh faktor lingkungan, baik teman sebaya, lingkungan masyarakat maupun media masssa seperti tayangan televisi dan internet. Dilema muncul apabila orang tua sudah menanamkan pola asuh dan nilai-nilai yang baik pada anak, namun karena pengaruh lingkungan, maka tidak mustahil anak menjadi berkepribadian tidak baik. Oleh karena itu, komunikasi, pengawasan dan pendampingan harus dilakukan orang tua agar anak mampu memilih dan memilah sikap serta perbuatan yang harus dicontoh dan tidak patut dicontoh.

Terkait dengan permainan, maka orang tua perlu memberikan kesempatan anak untuk bermain dan berbaur bersama melalui permainan. Ayah dan Ibu perlu menyediakan sarana dan media bermain untuk membantu mengembangkan potensi dan kepribadian anak. Tidak menjadi masalah apabila ayah mengajak anak perempuannya bermain bola, dan Ibu meminta anak laki-lakinya terlibat di dapur. Melalui permainan, anak dapat diberikan pemahaman untuk lebih mengenal karakter dan kekhasan masing-masing serta menghargai perbedaan. Misalnya tidak selamanya anak perempuan itu cengeng dan ternyata anak laki-laki pun diperbolehkan menangis.

\section{Peran Orang Tua}

Keluarga merupakan lembaga yang paling penting dalam membentuk kepribadian anak. Ki Hajar Dewantara menyatakan bahwa esensi pendidikan merupakan tanggung jawab keluarga, sedangkan sekolah hanya berpartisipasi (M Sochib, 2000). Orang tua memiliki peran paling besar untuk mempengaruhi anak pada saat anak peka terhadap pengaruh luar, serta mengajarnya selaras dengan temponya sendiri. Orang tua adalah sosok yang seharusnya paling mengenal kapan dan bagaimana anak belajar sebaikbaiknya (Dwi Sunar, 2007). Dalam 
proses perkembangan anak, peran orang tua antara lain:

\section{a. Mendampingi}

Setiap anak memerlukan perhatian dari orang tuanya. Sebagian orang tua bekerja dan pulang ke rumah dalam keadaan lelah. Bahkan ada juga orang tua yang menghabiskan sebagian besar waktunya untuk bekerja, sehingga hanya memiliki sedikit waktu bertemu dan berkumpul dengan keluarga. Bagi para orang tua yang menghabiskan sebagian waktunya untuk bekerja di luar rumah, bukan berarti mereka gugur kewajiban untuk mendampingi dan menemani anak-anak ketika di rumah. Meskipun hanya dengan waktu yang sedikit, namun orang tua bisa memberikan perhatian yang berkualitas dengan fokus menemani anak, se-perti mendengar ceritanya, bercanda atau bersenda gurau, bermain bersama dan sebagainya. Menyediakan fasilitas dan media bermain yang lengkap tidak menjamin anak merasa senang. Anak merupakan makhluk sosial yang memiliki kebutuhan sosial, yaitu ber-interaksi dengan orang lain, mendapatkan perhatian serta kehangatan dari orang-orang yang ada di sekitarnya.

b. Menjalin komunikasi

Komunikasi menjadi hal penting dalam hubungan orang tua dan anak karena komunikasi merupakan jembatan yang menghubungkan keinginan, harapan dan respon masing-masing pihak. Melalui komunikasi, orang tua dapat menyampaikan harapan, masukan dan dukungan pada anak. Begitu pula sebaliknya, anak dapat bercerita dan menyampaikan pendapatnya. Komunikasi yang diwarnai dengan keterbukaan dan tujuan yang baik dapat membuat suasana yang hangat dan nyaman dalam kehidupan keluarga. Saat bermain, orang tua dan anak menjalin komunikasi dengan saling mendengarkan lewat cerita dan obrolan.

c. Memberikan kesempatan

Orang tua perlu memberikan kesempatan pada anak. Kesempatan pada anak dapat dimaknai sebagai suatu kepercayaan. Tentunya kesempatan ini tidak hanya sekedar diberikan tanpa adanya pengarahan dan pengawasan. Anak akan tumbuh menjadi sosok yang percaya diri apabila diberikan kesempatan untuk mencoba, mengekspresikan, mengeksplorasi dan mengambil keputusan. Kepercayaan merupakan unsur esensial, sehingga arahan, bimbingan dan bantuan yang diberikan orang tua kepada anak akan "menyatu" dan memudahkan anak menangkap maknanya (M Sochib, 2000). Orang tua kadangkala perlu membiarkan anak per-empuannya bermain perang-perangan dan berlarian selama tidak membahayakan dan anak laki-lakinya yang ikut membeli pada per-mainan "masakmasakan".

d. Mengawasi

Pengawasan mutlak diberikan pada anak agar anak tetap dapat dikontrol dan diarahkan. Tentunya pengawasan yang dimaksud bukan berarti dengan memata-matai dan main curiga. Tetapi pengawasan yang dibangun dengan dasar komunikasi dan keterbukaan. Orang tua perlu secara langsung dan tidak langsung untuk mengamati dengan siapa dan apa yang dilakukan oleh anak, sehinga dapat meminimalisir dampak pengaruh negatif pada anak. Dalam kegiatan bermain, tentunya jenis permainan perlu diperhatikan agar anak laki-laki tidak terlalu menonjol (memiliki sikap kasar dan keras) dan atau kehilangan sisi maskulinitasnya (seperti perempuan). Begitu pula anak perempuan, terlalu menonjol sisi feminitasnya (terlalu sensitif 
atau cengeng) dan atau kehilangan sisi feminitasnya (tomboy).

e. Mendorong atau memberikan motivasi

Motivasi merupakan keadaan dalam diri individu atau organisme yang mendorong perilaku ke arah tujuan (Bimo Walgito, 2002). Motivasi bisa muncul dari diri individu (internal) maupun dari luar individu (eksternal). Setiap individu merasa senang apabila diberikan penghargaan dan dukungan atau motivasi. Motivasi menjadikan individu menjadi semangat dalam mencapai tujuan. Motivasi diberikan agar anak selalu berusaha mempertahankan dan meningkatkan apa yang sudah dicapai. Apabila anak belum berhasil, maka motivasi dapat membuat anak pantang menyerah dan mau mencoba lagi.

f. Mengarahkan

Orang tua memiliki posisi strategis dalam membantu agar anak memiliki dan mengembangkan dasar-dasar disiplin diri (M Sochib, 2000).

\section{Upaya yang Bisa Dilakukan}

Melalui permainan diharapkan dapat menumbuhkan pribadi androgynius pada anak-anak. Pola permainan yang dilakukan secara perlahan memungkinkan munculnya kepribadian yang terinternalisasi. Untuk menumbuhkan pribadi androgynius, maka orang dewasa dalam hal ini orang tua, angggota keluarga dan pendidik dapat melakukan beberapa hal, diantaranya:

a. Mengenalkan dunia lawan jenisnya

Anak perlu dikenalkan pada dunia lawan jenis, misalnya jenis permainan, kesempatan untuk memerankan permainan lawan jenis, kebiasaan berpakaian, dan sebagainya. Pola permainan yang dilakukan secara perlahan akan memberi bentuk kepribadian. Kesempatan untuk bergaul memu- ngkinkan anak tumbuh menjadi pribadi seimbang.

b. Memberikan kesempatan memerankan permainan lawan jenisnya

Memerankan permainan lawan jenis memiliki keasyikan tersendiri. Selain sebagai variasi, permainan ini dapat mengarahkan pada sisi kepribadian. Anak laki-laki bisa saja memainkan boneka untuk menumbuhkan feminitasnya. Mungkin tidak menggendong-gendong boneka seperti anak perempuan, tetapi bisa meletakkan boneka tersebut di atas mobil-mobilan layaknya penumpang (Irawati Istadi, 2007). Anak perempuan pun diperbolehkan untuk mengecat, memasang lampu, paku memaku dan sebagainya.

c. Mengijinkan sesekali berpakaian seperti lawan jenisnya (khusus anak perempuan)

Pada umumnya anak perempuan dibiasakan menggunakan rok. Namun kadangkala tidak ada salahnya apabila anak perempuan menggunakan celana agar lebih memungkinkan keleluasaan bergerak dan melakukan berbagai kegiatan maskulinitas, seperti berlarian, memanjat, dan bersepeda. Anak perempuan perlu dirangsang untuk melakukan kegiatan maskulinitas, meskipun porsinya tidak sebanyak laki-laki (Irawati Istadi, 2007). Bagi anak laki-laki, tentunya tidak perlu dilatih mengggunakan rok karena pada umumnya sesuai norma dan budaya kita, laki-laki menggunakan celana.

d. Membiarkan anak untuk berbaur

Melalui kegiatan bersama, anakanak akan memahami bahwa anak perempuan tidak selamanya identik dengan sifat cengeng. Anak perempuan juga memiliki karakter penyayang dan suka menolong. Sebaliknya anak perempuan juga bisa memahami bahwa anak lakilaki tidak hanya suka menggoda dan kadangkala membuat tangis (se- 
benarnya hanya bercanda), tapi juga bisa menjadi pembela ketika ada anak lain yang mengganggu. Ketika kadangkala anak-anak saling berbincang, pukul-pukulan, bercanda, saling dorong, maka biarkanlah karena melalui hal tersebut anak bisa saling mengenal. Pemberian batasan untuk dipisah apabila anakanak sudah beranjak 10 tahun (Irawati istadi, 2007).

\section{Penutup}

Orang tua memiliki peran untuk membantu mengoptimalkan tumbuh kembang anak, sehingga dapat mencapai tugas perkembangannya dengan baik. Salah satu lingkup perkembangan yang tidak kalah penting adalah sosial emosional, termasuk di dalamnya adalah kepribadian. Melalui kegiatan bermain, orang tua dapat membentuk pribadi anak yang androgynius dengan memperkenalkan anak-anak pada dunia lawan jenis. Tentunya pengenalan tersebut disesuaikan dengan porsi agar mencapai keseimbangan. Dalam artian anak laki-laki tidak menonjol karakter keperempuan-perempuanan dan anak perempuan tidak terlalu tampak kelaki-lakiannya (terlalu tomboy). Diharapkan dengan mengenal dan memperoleh pengalaman tentang kegiatan bermain lawan jenis, anak-anak lebih mampu menghayati, memahami dan menyikapi karakteristik lawan jenis serta tidak memiliki pribadi yang timpang dan kaku. Anak laki-laki tumbuh sebagaimana karakter dan sifat kelaki-lakiannya, namun tetap memiliki sifat feminin dalam kadar secukupnya seperti sabar, telaten dan lembut. Begitu pula anak perempuan, selain memiliki kepribadian feminin namun juga perlu memiliki sifat maskulin, seperti tegas, pemberani dan menyukai tantangan.

\section{Daftar Pustaka}

Istadi, Irawati. 2007. Istimewakan Setiap Anak. Bekasi: Pustaka Inti.

Prasetyono, Dwi Sunar. 2007. Membedah Psikologi Bermain Anak. Yogyakarta: Penerbit Think.

Rumini, Sri dkk. 1998. Psikologi Umum. Fakultas Ilmu Pendidikan IKIP Yogyakarta.

Sochib, M. 2000. Pola Asuh Orang Tua Dalam Membantu Anak Mengembangkan Disiplin Diri. J akarta: Rineka Cipta.

Suryadi. 2007. Cara Efektif Memahami Perilaku Anak Usia Dini. Jakarta: EDSA.

Suyanto, Slamet. 2003. Konsep Pendidikan Anak Usia Dini. Yogyakarta.

Walgito, Bimo. 2004. Pengantar Psikologi Umum. Yogyakarta: Penerbit Andi.

http:// n4il4.multiply.com/journal/ite m/229/ Awas-J angan-TerlaluKeras-Mendidik-Anak- diakses tanggal 12 September 2012 
J urnal Pendidikan Anak, Volume 1, Edisi 1, J uni 2012 